\section{Effect of recasting percentage of base metal alloys on the metal-ceramic bond strength}

\section{Kıymetsiz metal alaşımlarında artık metal kullanım yüzdesinin metal-seramik bağlantısına olan etkisi}

\section{Dr. Ayşe Gözde Türk}

Ege University, School of Dentistry, Department of Prosthodontics, Izmir

Received: 19 May 2017

Accepted: 20 June 2017

doi: 10.5505/yeditepe.2017.69885

\section{Corresponding author:}

Dr. Ayşe Gözde Türk

Ege University, School of Dentistry

Department of Prosthodontics, Bornova 35100 izmir Tel: 02323114651

E-mail: agturk@gmail.com

\section{SUMMARY}

Aim: Long-term success of metal ceramic restorations depends on metal ceramic bond. Recasting has been generally used for casted dental restorations in laboratories for economic reasons. This study was conducted to assess the effect of recasting percentage of $\mathrm{Co}-\mathrm{Cr}$ alloys on the bond strength of metal-ceramic.

Materials and Method: Different percentage combinations of new and once casted alloy were used to manufacture a total of fifty metal-ceramic samples for five groups $(n=10)$. Metal discs (5 mm high-5 mm in diameter) were casted from $100 \%$ new alloy (G1), $75 \%$ new-25\% once casted alloy (G2), $50 \%$ new-50\% once casted alloy (G3), 25\% new-75\% once casted alloy (G4), 100\% once casted alloy (G5). Opaque and dentin ceramics ( $4 \mathrm{~mm}$ high- $4 \mathrm{~mm}$ in diameter) were fired on the metal samples. Metal-ceramic samples were thermo cycled $\left(5-55^{\circ} \mathrm{C}, 5000\right.$ cycles), with a dwell time of $20 \mathrm{~s}$ and a 10 $s$ transfer time. The shear bond strength test was performed in a universal testing machine (Shimadzu) with a crosshead speed of $0.5 \mathrm{~mm} / \mathrm{min}$. Failure types were examined with a streomicroscope $(X 20)$. The data were analyzed with one-way ANOVA and the Tukey HSD test ( $p=0.05)$.

Results: The mean bond strengths (MPa) were; 80.67 for G1, 85.69 for G2, 81.25 for G3, 80.46 for G4, and 81.74 for G5. No significant difference was found between the groups ( $p>0.005)$. Cohesive failure types were seen for all groups.

Conclusion: Different percentages of new alloy and once casted alloy had similar bond strength values.

Key words: Recasting, base metal alloy, bond-strength

\section{ÖZET}

Amaç: Metal seramik restorasyonların uzun dönem başarısı metal seramik bağlantısına bağlıdır. Ekonomik sebeplerle, metal destekli restorasyonlarda genellikle artık metalin tekrar kullanımı yapılmaktadır. Bu çalışmanın amacı, Co-Cr alaşımlarda artık metal kullanım yüzdelerinin metal-seramik bağlantısına olan etkisinin araştırılmasıdır.

Gereç ve Yöntem: Yeni ve bir kez dökülmüş metallerin farklı yüzde kombinasyonları kullanılmış, her grupta 10 adet olmak üzere, toplamda 50 adet metal-seramik örnek elde edilmiştir. Beş mm yükseklik, $5 \mathrm{~mm}$ çapındaki metal disklerden guruplar sırasıyla, \%100 yeni metal (G1), \%75 yeni-\%25 artık metal (G2), $\% 50$ yeni-\%50 artık metal (G3), \%25 yeni-\%75 artık metal (G4), $\% 100$ artık metal (G5) kullanımıyla oluşturulmuştur. Opak ve dentin seramikleri $4 \mathrm{~mm}$ yükseklik, $4 \mathrm{~mm}$ çapında olacak şekilde metal örnekler üzerine pişirilmiştir. Örneklere $5-55^{\circ} \mathrm{C}$ aralığında, 20 sn bekleme, 10 sn banyolar arası transfer ve 5000 siklüs olacak şekilde termal yaşlandırma yapılmıştır. Metal-seramik örneklere makaslama bağ dayanım testi 0.5 $\mathrm{mm} / \mathrm{dk}$ çapraz hızla uygulanmıştır. Kırık tipleri ışık mikroskobu ile 20 büyütmede incelenmiştir. Elde edilen verilere Tek Yönlü Varyans ve Tukey testleri ile istatistiksel analiz uygulanmıştır $(p=0,05)$. 
Bulgular: Gurupların ortalama makaslama bağ dayanımları sırasıyla; G1=80,67 MPa, G2=85,69 MPa, G3=81,25 $\mathrm{MPa}, \mathrm{G} 4=80,46 \mathrm{MPa}$, ve G5=81,74 MPa olarak bulunmuştur. Gurupların bağ dayanım değerleri arasında istatistiksel olarak anlamlı bir fark bulunmamıştır ( $p>0.005)$. Kırık tipleri tüm guruplar için kohezivdir.

Sonuçlar: Çalışmamızın kısıtlamaları dahilinde, farklı oranlarla yeni metal ve bir kez dökülmüş artık metal içeren kıymetsiz alaşımlarının bağ dayanımları benzerdir. Anahtar kelimeler: Kıymetsiz metal alaşımı, bağ dayanımı, artık metal

\section{INTRODUCTION}

Despite the development and growing use of all ceramic systems, metal-ceramic restorations are still been used. For decades, gold has been used in dental practice. Overtime, when economic reasons and rigidity were considered, Ni based alloys have become popular. Properties of all nickel-based alloys are high hardness, higher modulus of elasticity, and higher melting temperature when compared with that of noble metal alloys. ${ }^{1}$ Because of the potential health hazard of nickel and beryllium present in nickel-based alloys, cobalt-based alloys have been introduced to the market. Castability, solderability, and bond strength of cobalt-based alloys are not as good as those of the nickel-based alloys containing beryllium. ${ }^{1}$ Because of they are harder and more technique-sensitive than are nickel-based alloys; reliable metal ceramic bond should be needed. Since long-term success of metal ceramic restorations depends on reliable metal ceramic bond. Base elements such as Fe, Sn, Zn and In are added to alloys in trace amounts for forming a strong metal ceramic bond. ${ }^{2,3}$ Recasting previously cast metal is being used at laboratories to decrease the cost of restorations. It is stated that recasting can affect the metal-oxide composition of fresh alloy that could compromise the metal ceramic bond. ${ }^{2}$

Manufacturing companies recommended that in order to achieve a clinically acceptable casting, recast metal should be combined with at least $50 \%$ new metals for gold alloys. ${ }^{4}$ However different percentages of recasted base metal alloy with new metal or different recasting times were declared in the literature. ${ }^{3-16}$ Published reports on the recasting of dental alloys vary widely, with opinions ranging from the complete avoidance of recasting to recasting up to 10 times without any changes in the alloy's quality. ${ }^{17}$ No consensus protocol has been established to evaluate recasting. Therefore, this study was conducted to assess the effect of recasting percentage of base metal alloys on the bond strength of metal-ceramic. The null hypothesis of this study was recasting does not have any effect on bond strength of base metal alloy and ceramic.

\section{MATERIALS AND METHODS}

Fifty wax patterns with dimensions of $5 \mathrm{~mm}$ in height and $5 \mathrm{~mm}$ in diameter were prepared. The wax patterns were sprued and invested in a phosphate-bonded investment, then placed in a burnout oven. Following burnout, the Co-Cr (IPS d.SIGN 20, Ivoclar Vivadent, Schaan, Liechtenstein) specimens were casted with different percentage combinations of new and once casted alloy. The first group was casted from $100 \%$ new alloy (G1), the second group was $75 \%$ new-25\% once casted alloy (G2), the third group was $50 \%$ new-50\% once casted alloy (G3), the fourth was $25 \%$ new-75\% once casted alloy (G4) and the fifth group was casted from $100 \%$ once casted alloy (G5) $(n=10)$ (Table 1).

Table 1: Different percentage combinations of new and once casted alloy the CoCr specimens.

\begin{tabular}{|c|c|}
\hline G1 & $100 \%$ new alloy \\
\hline G2 & $75 \%$ new- $25 \%$ once casted alloy \\
\hline G3 & $50 \%$ new-50\% once casted alloy \\
\hline G4 & $25 \%$ new- $75 \%$ once casted alloy \\
\hline G5 & $100 \%$ once casted alloy \\
\hline
\end{tabular}

After casting, all specimens were divested and sandblasted for 15 seconds using $110 \mu \mathrm{m}$ aluminum oxide $\left(\mathrm{Al}_{2} \mathrm{O}_{3}\right)$ particles at a 2-cm distance, 6-bar pressure. Prior to ceramic application, metal specimens were cleaned in ultrasonic distilled water for 30 min and placed in ethyl acetate.

Two layers of opaque porcelain were applied to metal surfaces using a brush and fired under a vacuum in a calibrated oven to a temperature of $900^{\circ} \mathrm{C}$. Dentin porcelain (IPS d.SIGN, Ivoclar Vivadent, Schaan, Liechtenstein) was then condensed into a removable plastic cap with dimensions of $4 \mathrm{~mm}$ in high and $4 \mathrm{~mm}$ in diameter, and fired under a vacuum in a calibrated oven to a temperature of $880^{\circ} \mathrm{C}$ according to the manufacturers' instructions.

After the specimens were thermo cycled $\left(5-55^{\circ} \mathrm{C}, 5000\right.$ cycles), with a dwell time of $20 \mathrm{~s}$ and a $10 \mathrm{~s}$ transfer time, shear bond strength (SBS) test $(0.5 \mathrm{~mm} / \mathrm{min}, 200 \mathrm{Kgf})$ was performed in a universal testing machine (Shimadzu, Tokyo, Japan) using a customized device until bonding failure (Figure 1).

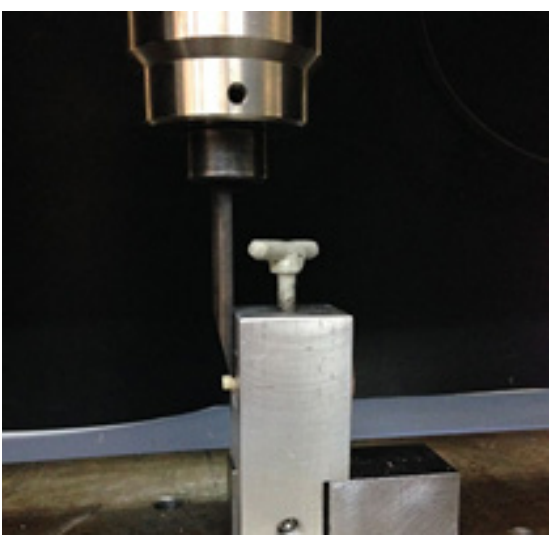

Figure 1: Shear bond strength test was applied to the tested samples. 
SBS values were recorded and surfaces were evaluated under a streomicroscope (Leica Dfc 295, Leica Microsystems, Bensheim, Germany) at 20X magnification to determine the failure types.

SBS values were statistically analyzed with Kolmogorov Smirnov, Levene, oneway ANOVA and multiple comparisons were made by Tukey's adjustment test, using SPSS 13.0 (SPSS, Chicago, IL, USA). Differences were considered significant at $\mathrm{p}=0.05$.

\section{RESULTS}

The mean, minimum, maximum and standard deviations of the groups are presented in Table 2.

Table 2: The mean, minimum, maximum and standard deviations of the groups (MPa). Same superscript letters indicate no statistical differences between the groups

\begin{tabular}{|c|c|c|c|c|}
\hline Groups & Mean (Mpa) & SD & Min & Max \\
\hline G1 (100\% N) & $80.67 a$ & 18.46 & 56.68 & 108.75 \\
\hline $\begin{array}{c}\text { G2 (75\% } \\
\mathbf{N}+\mathbf{2 5} \% \mathbf{R})\end{array}$ & $85.69 \mathrm{a}$ & 22.14 & 62.58 & 135.27 \\
\hline $\begin{array}{c}\text { G3 (50\% } \\
\mathbf{N}+\mathbf{5 0} \% \mathbf{R})\end{array}$ & $81.25 a$ & 22.15 & 46.02 & 127.88 \\
\hline $\begin{array}{c}\mathbf{G} \mathbf{4}(\mathbf{2 5} \% \\
\mathbf{N}+\mathbf{7 5} \% \mathbf{R})\end{array}$ & $80.46 a$ & 16.12 & 47.11 & 103.56 \\
\hline G5 (100\% R) & $81.74 a$ & 10.68 & 65.23 & 95.22 \\
\hline
\end{tabular}

$\mathbf{N}=$ New $\quad \mathbf{R}=$ Recasted

The mean shear bond strength of values of G1, G2, G3, G4 and G5 were 80.67 MPa, 85.69 MPa, 81.25 MPa, 80.46 $\mathrm{MPa}$, and $81.74 \mathrm{MPa}$ respectively. One-way ANOVA are presented in Table 3.

Table 3: One-way ANOVA results for shear bond strength

\begin{tabular}{|c|c|c|c|c|c|}
\hline & $\begin{array}{c}\text { Sum of } \\
\text { Squares }\end{array}$ & df & $\begin{array}{c}\text { Mean } \\
\text { Square }\end{array}$ & F & Sig. \\
\hline $\begin{array}{c}\text { Between } \\
\text { Groups }\end{array}$ & 183.4 & 4 & 45.857 & .135 & .969 \\
\hline $\begin{array}{c}\text { Within } \\
\text { Groups }\end{array}$ & 15270.5 & 45 & 339.346 & & \\
\hline Total & 15453.9 & 49 & & & \\
\hline
\end{tabular}

indicating that there were not significant differences between alloy-ceramic combinations tested ( $p>0.05)$. Failure types were predominantly cohesive between metal and opaque for all groups (Figure 2).

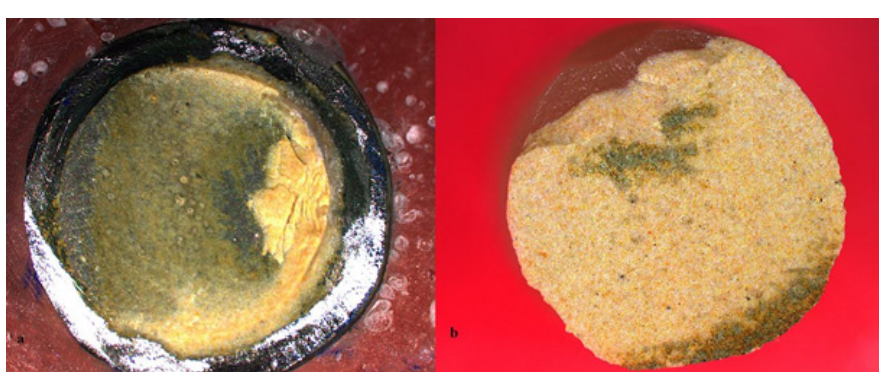

Figure 2: Representative images of cohesive failure type between a) metal and b) ceramic (opaque layer)

\section{DISCUSSION}

According to the results of the study, adding or using once recasted alloy did not have any effect on bond strength of base metal alloy and ceramic. Thus, the null hypothesis was accepted. The shear bond test is commonly used to evaluate the bond strength between alloys and ceramic. Sipahi et al reported shear bond strength of CoCr base metal alloys as $13.3 \mathrm{MPa}$ to $19 \mathrm{MPa} .{ }^{18}$ Prado et al compared shear bond strength of 3 nickel-chromium alloys to porcelain and reported values ranging from 16.31 MPa to $32.93 \mathrm{MPa} .{ }^{19}$ De Melo et al. compared shear bond strength between 4 base metal alloys ( 2 nickel chromium and 2 cobalt chromium) and dental ceramic and reported bond strength values ranging between $54 \mathrm{MPa}$ and 71.7 $\mathrm{MPa}^{20}$

Joias et al. reported that shear bond strength values of Co-Cr alloys were $63 \mathrm{MPa}$ to $96 \mathrm{MPa} .{ }^{21}$ Akova et al. also reported the shear bond strength values of $\mathrm{Ni}-\mathrm{Cr}, \mathrm{Co}-\mathrm{Cr}$ and laser sintered alloys ranging from $67 \mathrm{MPa}$ to 81.6 MPa. ${ }^{22}$ Similar to the results of de Melo et al., Akova et al. and Joias and colleagues, In the present study, bond strength values of ceramic to Co-Cr alloys were ranging from 80.46 Mpa to 85.69 MPa.

Uçar et al evaluated the effect of multiple casting on the bond load of base metal alloy and ceramic and they had 4 groups: first one was a hundred percent fresh alloy, The other groups were prepared with the addition of $50 \%$ of fresh alloy each time to the remnants of the previous group. They reported that including recast base alloy with fresh alloy decreases metal-to-ceramic bond strengths. ${ }^{3}$ Similar to the results of Uçar and colleagues, Madani et al. stated that by adding over $50 \%$ once-cast alloy in base-metal alloys, metal-ceramic bond strength decreases significantly. ${ }^{7}$

On the other hand our results showed that, adding (mixture of) once recasted alloy did not have any effect on bond strength of base metal alloy and ceramic. In accordance with our results, Hesby et al reported, repeated casting had no effect on the physical properties of base-metal alloys. ${ }^{15}$ Nelson et al. also reported that recasting $\mathrm{Ni}-\mathrm{Cr}$ alloys had no effect on physical properties, microstructures, and clinical features of these alloys. ${ }^{16}$ In our study, shear bond strength test was preferred to evaluate the effect of recasting percentage on metal-ceramic bond. Further studies comparing the methodology used in this study to other types of metal ceramic bond strength testing such as 3-point or 4-point bending tests are needed.

\section{CONCLUSION}

Within the limitations of this in-vitro study, base metal alloys whether new or once casted had similar metal-ceramic bond strengths. Failure types were cohesive between metal and opaque. 


\section{ACKNOWLEDGEMENTS}

The author would like to thank to Dalkaya Dental Laboratory for preparing the specimens.

\section{REFERENCES}

1.Asgar K. Casting metals in dentistry: past--present--future. Adv Dent Res 1988; 2: 33-43.

2.Ayad MF. Compositional stability and marginal accuracy of complete cast crowns made with as-received and recast type III gold alloy. J Prosthet Dent 2002; 87: 162166.

3.Ucar Y, Aksahin Z, Kurtoglu C. Metal ceramic bond after multiple castings of base metal alloy. J Prosthet Dent 2009; 102: 165-171.

4. Reisbick MH, Brantley WA. Mechanical property and microstructural variations for recast low-gold alloy. Int $J$ Prosthodont. 1995; 8: 346-350.

5.Akyil, $M$, Duymuş Z. Evaluation of the effect of recast metal addition, plating and oxidation temperature on metal-porcelain Bond strength in non-precious alloys. Clin Dent Res 2009, 33: 2-13.

6.Atluri KR, Vallabhaneni TT, Tadi DP, Vadapalli SB, Tripuraneni SC, et al. Comparative Evaluation of Metal-ceramic Bond Strengths of Nickel Chromium and Cobalt Chromium Alloys on Repeated Castings: An In vitro Study. J Int Oral Health 2014; 6: 99-103.

7.Madani AS, Rokni SR, Mohammadi A, Bahrami M. The effect of recasting on bond strength between porcelain and base-metal alloys. J Prosthodont 2011; 20: 190-194. 8. Henriques GE, Consani S, Rollo JM, Andrade e Silva F. Soldering and remelting influence on fatigue strength of cobalt-chromium alloys. J Prosthet Dent 1997; 78: 146152.

9.Kul E, Aladag LI, Duymus ZY. Comparison of the metal-ceramic bond after recasting and after laser sintering. J Prosthet Dent 2015; 114: 109-113.

10.Gupta S, Mehta AS. The effect of remelting various combinations of new and used cobalt-chromium alloy on the mechanical properties and microstructure of the alloy. Indian J Dent Res 2012; 23: 341-347.

11.Oyar $P$, Can $G$, Atakol O. Effects of environment on the release of $\mathrm{Ni}, \mathrm{Cr}, \mathrm{Fe}$, and $\mathrm{Co}$ from new and recast $\mathrm{Ni}-\mathrm{Cr}$ alloy. J Prosthet Dent 2014; 112: 64-69.

12.Ozdemir S, Arikan A. Effects of recasting on the amount of corrosion products released from two $\mathrm{Ni}-\mathrm{Cr}$ base metal alloys. Eur J Prosthodont Restor Dent 1998; 6: 149-153.

13.Imirzalioglu P, Alaaddinoglu E, Yilmaz Z, Oduncuoglu $B$, Yilmaz B, et al. Influence of recasting different types of dental alloys on gingival fibroblast cytotoxicity. J Prosthet Dent 2012; 107: 24-33.

14. Yavuz $T$. Effect of surface treatment on elemental composition of recast NiCr alloy. Mater Sci Appl 2012; 3: 163-167.
15. Hesby DA, Kobes P, Garver DG, Pelleu GB Jr. Physical properties of a repeatedly used nonprecious metal alloy. J Prosthet Dent 1980; 44: 291-293.

16.Nelson DR, Palik JF, Morris HF, Comella MC. Recasting a nickel-chromium alloy. J Prosthet Dent 1986; 55: 122-127.

17.Vaillant-Corroy AS, Corne P, De March P, Fleutot S, Cleymand $F$. Influence of recasting on the quality of dental alloys: A systematic review. J Prosthet Dent 2015; 114: 205-211.e3.

18.Sipahi C, Ozcan M. Interfacial shear bond strength between different base metal alloys and five low fusing feldspathic ceramic systems. Dent Mater J 2012; 31: 333337.

19.do Prado RA, Panzeri H, Fernandes Neto AJ, das Neves FD, da Silva MR, et al. Shear bond strength of dental porcelains to nickel-chromium alloys. Braz Dent J 2005; 16 : 202-206.

20.de Melo RM, Travassos AC, Neisser MP. Shear bond strengths of a ceramic system to alternative metal alloys. J Prosthet Dent 2005; 93: 64-69.

21.Joias RM, Tango RN, Junho de Araujo JE, Junho de Araujo MA, Ferreira Anzaloni Saavedra Gde S, et al. Shear bond strength of a ceramic to Co-Cr alloys. J Prosthet Dent 2008; 99: 54-59.

22.Akova T, Ucar Y, Tukay A, Balkaya MC, Brantley WA. Comparison of the bond strength of laser-sintered and cast base metal dental alloys to porcelain. Dent Mater 2008; 24: 1400-1404. 